\title{
INSTITUTIONAL SUPPORT FOR LOCAL COMMUNITIES WITHIN WASTE MANAGEMENT POLICIES, BASED ON THE EXAMPLE OF THE NFEP\&WM PROGRAMME
}

\author{
DAGMARA HAJDYS, ${ }^{1}$ MAGDALENA KOGUT-JAWORSKA ${ }^{2}$
}

\author{
${ }^{1}$ Uniwersytet Łódzki, POLAND \\ e-mail: dagmara.hajdys@uni.lodz.pl \\ ${ }^{2}$ Uniwersytet Szczeciński, POLSKA \\ e-mail: magdalena.kogut@wzieu.pl
}

RECEIVED
ACCEPTED
JEL
CLASSIFICATION

CLASSIFICATION

KEYWORDS municipal wastes, collection and recovery, task of commune, sources of funding

ABSTRACT

4 December 2017

5 January 2018

F42, F63, H41, H87
According to the guidelines for ecological policies of the state regarding collection, storage, utilization and disposal of waste, their rational management should ensure satisfactory condition of the natural environment. The absolute priority for waste management policy is given to minimalisation of negative influence of waste on the environment. Actions taken recently by local authorities should improve the conditions for waste management, as well as they are aimed at achieving the standards required by the Polish and European Union Laws. In this context, the goal of this paper is to identify some aspects connected with financing of waste management by Polish local communities, and to indicate methods of institutional support, mainly coming from the National Fund for Environmental Protection and Water Management (NFEP\&WM). The paper present tasks for local communities in waste management policies and the role of NFEP\&WM in the system of institutional support. The paper also describes the main financial instruments for the local communities within the framework of waste management created by the NFEP\&WM.

\section{The authority of local communities within municipal waste management}

According to the existing parliamentary act (Act of 2012), waste management includes: collection, transport, and processing of waste, together with the supervision over these actions, as well as the proceedings concerning places of disposal, or actions concerning sale of waste (Act of 2012). The notion of waste management can be understood as ventures, actions or procedures which are connected with limiting of waste production, its utilization 
and disposal, as well as with its reusing or recycling (Famielec, 2017). The notion comprises planning, implementation and control of the actions performed. In particular, the aspects of waste management include (Famielec, 2017):

- legal regulations, guidelines, norms and standards for waste generation and utilization,

- plans for waste management at the local, regional, national and international level,

- reporting which refers to generating and utilization of waste, i. a.: permits for certain amount of the waste generated, its composition and types,

- issues connected with defining properities of various kinds of waste, its composition, toxicity etc., and also with the estimates for future amount and types of waste,

- collection and transport of waste,

- processing of waste, methods and technologies of recycling, processing for energy production or other forms of utilization,

- issues related to waste disposal through its dumping in landfills, technologies of waste storage, problems of environment management and other emerging issues.

The scope of responsibility of state agencies for municipal waste management is precisely explained in the acts of low. In accordance with the current regulations, territorial government units and local communities have been burdened with obligations to introduce and implement a waste management system. The new legal order and crucial accommodative measures, which have taken place since 2013, enlarge the scope of competence and authority of local communities within measures aimed at organizing and supervising of waste management, particularly at the selective collection and processing of waste. The legal changes were introduced by the revised act on cleanness and tidiness in local communities, which together with a new law on waste (management which contains more general regulations), is a basic legal act which specifies the issues in question (compare Table 1)

Table 1. Legal and organizational regulations at the national, regional and local levels having predominant influence on the municipal waste management system

\begin{tabular}{|c|c|c|}
\hline Regulation & Specifics & Description \\
\hline 1 & 2 & 3 \\
\hline \multirow[t]{2}{*}{$\begin{array}{l}\text { Legal acts and } \\
\text { regulations from } \\
\text { state authorities }\end{array}$} & $\begin{array}{l}\text { Act of Parliament, in particular: } \\
\text { The Act on Cleanness and Tidiness in local } \\
\text { communities - consolidated act. 13/09/1996, } \\
\text { Journal of Laws of the Republic of Poland No } \\
\text { 132, item. } 622 \text {, with later changes }\end{array}$ & $\begin{array}{l}\text { Sets conditions for municipal waste collection from real estate owners and for } \\
\text { utilization of the waste. It also regulates granting licenses for subjects offering } \\
\text { services regulated by the Act }\end{array}$ \\
\hline & $\begin{array}{l}\text { Act of Parliament from 14th December } 2012 \text { - } \\
\text { consolidated act. } \\
\text { Journal of Laws of the Republic of Poland } \\
2013 \text {, item } 21 \text { with later changes }\end{array}$ & $\begin{array}{l}\text { Determines measures which serve environment protection, including their } \\
\text { influence on human health and living conditions. The measures are expected to } \\
\text { diminish a negative impact resulting from waste production and its management, } \\
\text { and to scale down general implications of exploitation of resources, also aiming } \\
\text { at improved effectiveness of their utilisation }\end{array}$ \\
\hline $\begin{array}{l}\text { National } \\
\text { framework }\end{array}$ & $\begin{array}{l}\text { National plan for waste management } \\
2014-2023\end{array}$ & $\begin{array}{l}\text { Sets goals and tasks for waste management policies for } 2011-2014 \text {, with } \\
\text { additional perspective over 2015-2022. The document comprises both, } \\
\text { a programme preventing waste production and a strategy to reduce storage of } \\
\text { biodegradable waste }\end{array}$ \\
\hline $\begin{array}{l}\text { Regional } \\
\text { framework }\end{array}$ & Regional plans for waste management & $\begin{array}{l}\text { Determine a partition of geographical regions into regions outlined for municipal } \\
\text { waste management, also selecting local communities for certain activities. } \\
\text { The plans also indicate regional installations for municipal waste processing in } \\
\text { particular regions and installations selected for substitutive servicing of those } \\
\text { regions }\end{array}$ \\
\hline
\end{tabular}




\begin{tabular}{ll}
\hline \multicolumn{1}{c}{1} & \multicolumn{1}{c}{2} \\
\hline Act of law & In particular, resolutions concerning the following matters: \\
made by local & - collection of municipal waste from real estate owners, \\
authorities & - participation of the local community area into sectors for which the waste is collected, \\
& - regulations for maintenance of cleanness and tidiness in the local community, \\
& - specific methods and scope of services regarding waste collection, \\
& - choice of the method for establishing fees for waste management (including fees for waste containers), \\
& - times, frequency and methods of payment for municipal waste management \\
\hline
\end{tabular}

Source: own material.

Self-governing communities are responsible for the condition of the natural environment and maintenance of cleanness and order in their territories, which leads to better quality of life of the local community. Particular tasks for the communities in this respect have been clarified in the regulations which state that all inhabitants have to be included into the organized system of municipal waste collection. The local communities are also obliged to coordinate the system of selective collection of the waste. The responsibilities of local communities in the local policies, divided into main organizational stages, have been presented in the table below (Table 2.).

Table 2. Tasks for the local community within waste management policies

\begin{tabular}{|c|c|}
\hline Organisation and planning & $\begin{array}{l}\text { - Organisation of a waste management system by all inhibitants of the community. } \\
\text { - Analysis of the present state of waste management, needs of inhabitants in this respect, amount of waste created, } \\
\text { condition of the infrastructure, cost of maintenance of the system etc. } \\
\text { - Preparation and approval (by the local community council) of regulations for maintenance of cleanness and order } \\
\text { in the territory }\end{array}$ \\
\hline $\begin{array}{l}\text { Selective collection of } \\
\text { municipal waste }\end{array}$ & $\begin{array}{l}\text { - Offering the inhabitants possibilities of selective household waste collection, comprising, the following types of } \\
\text { waste: paper, metal, plastics, glass, multi-material packages and biodegradable waste. } \\
\text { - Establishment of a stationary collection point for selective collection (a "PSZOK") for the remaning household } \\
\text { waste, such as: past the expiration date medicine, flat batteries, end-of-life electric appliances, worn tires, pieces of } \\
\text { furniture or other big dimension objects, or any other described by the law }\end{array}$ \\
\hline $\begin{array}{l}\text { Collection of municipal } \\
\text { waste }\end{array}$ & - Choice of a contractor for collection or utilization, of municipal waste from property owners \\
\hline $\begin{array}{l}\text { Fees for municipal waste } \\
\text { management }\end{array}$ & $\begin{array}{l}\text { - Establishing and legislating methods of charging and rates of fees. The fees for waste management bring income } \\
\text { for the local community and can be spent only on covering the cost of waste management system }\end{array}$ \\
\hline $\begin{array}{l}\text { Regional installations for } \\
\text { municipal waste processing }\end{array}$ & $\begin{array}{l}\text { - Construction, maintenance and upkeep of own (or shared with other communities) installations for municipal waste } \\
\text { processing (the "RIPOK"), as long as such obligations result from the regional plan for waste management }\end{array}$ \\
\hline Tenders & $\begin{array}{l}\text { - Public tender has to be organised for municipal waste collection, or collection combined with proper management } \\
\text { and utilization }\end{array}$ \\
\hline $\begin{array}{l}\text { Declarations registries and } \\
\text { record keeping }\end{array}$ & $\begin{array}{l}\text { - Establishing a declaration form template and conditions for submission of declarations concerning rates of fees for } \\
\text { municipal waste management. } \\
\text { - Running a registry of activities subjected to municipal waste collection rules. The registry should be written into } \\
\text { a digital database. } \\
\text { - Running various registers, among other, a register of contracts signed for municipal waste collection from real } \\
\text { estate owners }\end{array}$ \\
\hline $\begin{array}{l}\text { Supervision and financial } \\
\text { reporting }\end{array}$ & $\begin{array}{l}\text { - Supervision of municipal waste management, including implementation of tasks ordered to subjects which collect } \\
\text { municipal waste from the households. } \\
\text { - Analysis of the state of municipal waste management has to be made basing on existing reports and other } \\
\text { accessible data which influence the cost of the municipal waste management system }\end{array}$ \\
\hline Information and education & $\begin{array}{l}\text { - Information concerning methods and rules of dealing with household waste has to be made available for the } \\
\text { inhabitants }\end{array}$ \\
\hline
\end{tabular}

Source: Stachowicz (2016). 
The authority to take actions is an important element of presumption of ownership of the local community organs. This concerns all public issues of the local character which have not been reserved on behalf of other subjects. In this context, it is a crucial obligation for the local community to organize an efficient system of dealing with municipal waste, However, the necessary scheme of such importance requires considerable organizational effort supported by well-organised financing.

\section{Institutional support for financing of investment activity within municipal waste management}

The authority to act and execute given to local communities within municipal waste management and the resulting responsibilities regarding collection and utilization of the waste require an array of actions (including investment) which ensure high efficiency of the system dealing with waste management. Investment activity in this area mainly comes down to contracting, maintenance and upkeep of own, or shared with other communities, regional installations for municipal waste processing (the RIPOK). Investment activity conducted this way, has to limit investment opportunities in some ventures regarded as less effective economicly and technologically (Zabek, 2013; Zielińska, 2017).

In needs to be stressed that institutional conditions for municipal waste management include central and local government agencies and institutions, as well as legal acts, such as (Famielec, 2017):

- local community,

- local community council,

- sanitary inspector for the district,

- regional sanitary inspector,

- real estate owner,

- the subject (administrative or business entity) which collects waste,

- legal acts and regulations concerning: waste management, natural environment protection, taxes and fees, i.a.: those referring to production and storage processes,

- acts on the local community,

- anti-trust law,

- licences for various services and conditions for granting such licences (for entrepreneurs). Entities of the local community which conduct activities on their territory do not need to have a licence, but they must meet certain requirements and standards (e.g.: the European Union Standards).

The necessity to implement certain actions concerning waste management requires not only legal regulations, but possibilities of effective financing, as well. Investors undertaking investment activity connected with waste management, which are most often local and district self-governments or municipal co-partnerships, have a wide array of possibilities to obtain financial support. Application of some of them has a compensatory character, but the use of other ones can have stimulative features. Instruments of institutional support include financial means (subsidies) in the following forms:

- subsidies and regional funds for co-financing pro-ecological ventures,

- preferential rules of crediting ventures connected with natural environment protection,

- income tax reductions or exemptions at realization of pro-ecological investment.

The basic links of the system - based on the principle that income from fees and fines related to natural environment exploiting should be committed to its protection - are the national and the sixteen regional environmental 
protection funds which offer broad financial support in the forms of grants, loans redemption and amortization of loans or interest repayment, as well as municipal bond issue and partial repayment of interest on such bonds.

Activity of such institutions supports, motivates and dynamises realization of pre-ecological ventures by local self-governments. Environment protection funds (NFEP\&WM and RFEP\&WM) set priorities for the beneficiaries of the financial support. In particular, the regional funds estimate the amount of support analysing the level of commitment and ways of cooperation with self-governments. Financial aid is most often channelled towards realization of pro-ecological investment of particular importance for local and regional development. The analysis of the fund performance so far, indicates that around a half of the means being at their disposal has been streamlined toward water quality protection or improvement of water resources, which resulted in considerable enhancement of water resources and gradual improvement of municipal infrastructure, mainly water and sewage pipes in local communities. Currently, a meaningful stream of financial means is transferred for realization of tasks connected with construction of waste - sorting plants and stations, establishing systems of waste retention and separate waste collection, modernization of waste storage places and land fills in connection with improved segregation of waste material, as well as closing down unnecessary landfills followed by recultivation of devastated areas.

It must be stressed that availability of the European Union funds is a positive factor creating better financing opportunities for waste management policies at the both, national and regional level. The financial aid comes from national and regional operational programmes.

\section{Financial instruments of The National Fund for Environmental Protection and Water Management for Iocal communities within the national waste management programme}

The National Fund for Environmental Protection and Water Management (NFEP\&WM) has launched a priority programme Rational Waste Management within the actions of the 2.2 Operational Programme for Infrastructure and Environmental 2014-2020 (the POIŚ). Its aim is to rationalize waste management through (NFEP\&WM, 2018):

- prevention of waste appearance,

- establishment and maintenance of widespread systems of selective waste collection,

- creation and maintenance of a nationwide, integrated waste management installations,

- diminishing of waste amount being illegally displaced between countries,

- intensification of collection and legal dismantling of end-of-life vehicles,

- upgrading of ecological awareness in the society.

The programme consist of five following parts:

- Part 1 - Prevention of waste creation and selective waste collection.

- Part 2 - Waste management installations.

- Part 3 - Modernisation of vehicle dismantling stations.

- Part 4 - Financial support for collecting and dismantling of end-of-life vehicles.

- Part 5 - International relocation of waste.

The program is aimed at territorial self-government units and their associations, at entrepreneurs, as well as at organs of public administration. Applications from them are continuously received and processed. The total amount for the realization of the programme is $1,771,191,000$ PLN. The co-financing can take the non-repayable form of a grant, with the total of $387,417,000 \mathrm{PLN}$ or a repayable form of a loan with the total of $1,383,774,000 \mathrm{PLN}$. The forms of co-financing and the beneficiaries of particular parts of the programme are shown in Table 3. 
Table 3. Forms of co-financing and beneficiaries of the Rational Waste Management programme

\begin{tabular}{|c|c|c|}
\hline Part and name of the programme & Form of-financing & Beneficiary of the programme \\
\hline 1. Selective collection and prevention of waste & $\begin{array}{l}\text { Grant } \\
\text { Loan }\end{array}$ & $\begin{array}{l}\text { Territorial self-government units and their } \\
\text { associations, entrepreneurs, Polish Hunting } \\
\text { Association, hunting clubs of the Polish } \\
\text { Hunting Association }\end{array}$ \\
\hline 2. Waste management installations & Loan & $\begin{array}{l}\text { Territorial self-government units and their } \\
\text { associations, entrepreneurs, }\end{array}$ \\
\hline 3. Modernisation of vehicle dismantling stations & Loan & Entrepreneurs, Vehicle, dismantling stations \\
\hline $\begin{array}{l}\text { 4. Co-financing of collection and dismanting of } \\
\text { end-of-life vehicles }\end{array}$ & Grant & $\begin{array}{l}\text { Local communities and counties which hand } \\
\text { over end-of-life vehicles to the dismantling } \\
\text { stations }\end{array}$ \\
\hline 5. International relocation of waste & $\begin{array}{l}\text { Money transfer to the current account of } \\
\text { the Ministry of Environment Protection for } \\
\text { co-financing environtal and water resources } \\
\text { protection measures which are implemented } \\
\text { by the budget of the state }\end{array}$ & $\begin{array}{l}\text { Public Administration organs, including the } \\
\text { General Inspector for Environment Protection }\end{array}$ \\
\hline
\end{tabular}

Source: own material based on the NFEP\&WM, https://nfosigw.gov.pl/oferta-finansowania/srodki-krajowe/programy-priorytetowe/racjonalnagospodarka-odpadami/\#c1 (20.02.2018).

The two first parts of the programme and the fourth one are addressed at the territorial self-government units. Companies can apply for the participation in the first three parts. The fifth part is addressed at public administration organs. Within the first part of the programme: "Selective collection and prevention of waste", local communities can apply for co-financing of actions connected with construction of the following:

- stationary points of selective household waste collection,

- pilot systems of selective household bio-waste from real estate owners,

- pilot systems of selective household waste collection for multi-apartment housing estates,

- further equipping of selective waste collection systems,

- development of technical infrastructure for logistic processes connected with obtaining, storage and distribution of unsold or unconsumed foodstuffs.

Beneficiaries can obtain co-financing in the form of a grant up to $100 \%$ of the qualified costs connected with investment on infrastructure, and up to $30 \%$ of the construction cost of the pilot selective systems for waste collection. In case of a loan, the maximum amount can be up to $90 \%$ of the qualified cost, at the 3M WIBOR rate not below $1 \%$ annually. Quarterly repayment period has been chosen here (Selektywne..., 2018). The programme "Installations for waste management" has been launched for the following scope of ventures planned by the local communities:

- new construction extension or modernization of the existing regional installations for municipal waste processing (the RIPOK), as well as the multi-regional installations for the same purpose,

- recycling of selectively collected municipal waste,

- construction, extension and modernization of existing installations for the waste other than municipal waste.

Loans up to $75 \%$ of the qualified cost have been introduced at the $3 \mathrm{M}$ WIBOR+ 50 base points, not less than $2 \%$ annually. The NFEP\&WM has planned a co-financing period no longer than 15 years. Beneficiaries who apply for a loan bigger than $4 \mathrm{mln}$ PLN are obliged to include a feasibility study. The National Found also subsidises 
collection of end-of -life vehicles within the programme: "Co-financing of collection and dismantling of and-of-life vehicles". An application form for the subsidy can be lodged by local communities, towns and capital towns of the counties which have collected and sent end-of-life vehicles for dismantling. The level of the subsidy is determined by the number of vehicles and amounts to 1,000 PLN for each of the first ten vehicles, and 500 PLN for each consecutive one (NFEP\&WM, 2018).

In 2017, within the programme Actions 2.2. Rational Waste Management, the National Fund was receiving, in the first place, applications for co-financing of selective municipal waste collection (the PSZOK). As a result of substantative assessment, 6 contract agreements were signed for the total amount of $33,400,000$ PLN. Applications for 8 investments, other than construction are being analysed by the PSZOK fund. The applied total co-financing amounts to 142,900,000 PLN (NFEP\&WM, 2018) .

\section{Conclusions}

Local communities have been assigned with objectives aimed at achieving and maintaining a satisfactory level of order and tidiness related to waste management. A wide array of existing regulations influence the local markets of waste management and the relation between the plans and the ways of realization by the subjects involved. Local communities, as a result of competence and authority given by the law, have a dominant position in the system of waste management. They create and supervise this system, prevent excessive production of harmful waste, have influence on recycling or related processes and the final disposal.

Construction and maintenance of the necessary facilities and equipment for waste management is also an important objective for local communities. Realization of the goals for waste management policies requires a wellfunctioning system of financing. Support from various funds available can not be underestimated in the analysis. Financial means for investment activity of the communities are distributed by, i. a., the NFEP\&WM in the form of grants or prefferencial loans. Currently, as data show, they constitute - due to a large scale of the undertaken ventures - a common and attractive source of support for active municipal waste management policies.

\section{References}

Famielec, J (2017). Gospodarka odpadami komunalnymi jako działalność gospodarcza realizowana w ogólnym interesie gospodarczym. In: M. Kożuch (ed.), Pomoc publiczna doświadczenia wybranych sektorów gospodarki, Kraków: Uniwersytet Ekonomiczny w Krakowie.

NFEP\&WM (2018). Racjonalna gospodarka odpadami. Retrieved from: https://nfosigw.gov.pl/oferta-finansowania/srodki-krajowe/ programy-priorytetowe/racjonalna-gospodarka-odpadami/\#c1 (12.02.2018).

Rozporządzenie Ministra Środowiska z dnia 14 grudnia 2016 r. w sprawie poziomów recyklingu, przygotowania do ponownego użycia oraz odzysku innymi metodami niektórych frakcji odpadów komunalnych, Dz.U. 2016, poz. 2167.

Rozporządzenie Ministra Środowiska z dnia 17 czerwca 2016 r., w sprawie wzorów sprawozdań o odebranych i zebranych odpadach komunalnych, odebranych nieczystościach ciekłych oraz realizacji zadań z zakresu gospodarki odpadami komunalnymi, Dz.U. 2016, poz. 934.

Rozporządzenie Ministra Środowiska z dnia 25 maja 2012 r. w sprawie poziomów ograniczania masy odpadów komunalnych ulegających biodegradacji przekazywanych do składowania oraz sposobu obliczania poziomu ograniczenia masy tych odpadów, Dz.U. 2012, poz. 676.

Rozporządzenie Ministra Środowiska z dnia 29 grudnia 2016 r. w sprawie szczegółowego sposobu selektywnego zbierania wybranych frakcji odpadów, Dz.U. 2017, poz. 19.

Selektywne zbieranie i zapobieganie powstawaniu odpadów (2018). NFOŚiGW. Retrieved from: file://C:/Users/user/Downloads/ program_2.1.1.pdf (21.02.2018). 
Stachowicz, M. (2016). Obowiązki gminy w zakresie gospodarki odpadami komunalnymi. Acta Scientifica Academiae Ostroviensis. Sectio A, Nauki Humanistyczne, Społeczne i Techniczne, ASO.A.7(1)/2016/119-134.

Ustawa z dnia 13 września 1996 r. o utrzymaniu czystości i porządku w gminach, Dz.U. 2017, poz. 2422.

Ustawa z dnia 14 grudnia 2012 r. o odpadach - tekst jednolity, Dz.U. 2013, poz. 21 z późn. zm.

Ustawa z dnia 14 grudnia 2012 r. o odpadach Dz.U. 2013, poz. 21.

Ustawa z dnia 27 sierpnia 2009 r. o finansach publicznych, Dz.U. nr 157, poz. 1240 z poźn. zm.

Ustawa z dnia 8 marca 1990 r. o samorządzie gminnym, Dz.U. nr 16, poz. 95 z późn. zm.

Ustawy z dnia 27 kwietnia 1989 r. o zmianie ustawy o ochronie i kształtowaniu środowiska i ustawy - Prawo wodne, Dz.U. nr 26, poz. 139 z późn. zm.

Ząbek, E. (2013). Nowe zasady gospodarowania odpadami komunalnymi. In: W. Pływaczewski, S. Buczyński (eds.), Gospodarka odpadami. Problematyka prawna i ekokryminologiczna. Olsztyn: Zakład Poligraficzny Uniwersytetu Warmińsko-Mazurskiego w Olsztynie.

Zielińska, A. (2017). Funkcjonowanie systemu finansowania gospodarki odpadami w polskich gminach. Retrieved from: http://elartu. tntu.edu.ua/bitstream/lib/20942/2/DSESES_2017_Zielinska_A-Funkcjonowanie_systemu_41-43.pdf (30.01.2018).

Cite this article aS: Hajdys, D., Kogut-Jaworska, M. (2018). Institutional support for local communities within waste management policies, based on the example of the NFEP\&WM Programme. European Journal of Service Management, 1 (25), 109-116. DOI: 10.18276/ ejsm.2018.25-13. 